\title{
MAKNA KASIH DALAM YOH. 21:15-19
}

\author{
Mida Purba \\ STKIP Widya Yuwana \\ midapurba@yahoo.com
}

\begin{abstract}
All people is longing for love. No one can escape from this fact. Inspire of this fact human being are often have little courage to love others truly. It is because they are driven by their ego and want to fulfill it. The consequence is they see other people as a person to fulfill their ego in a subtle way. As a Christian, Love is not only about loving others as a human being but love also has spesific meaning as God's love to human being. In order to gain a good understanding about the meaning of love, this paper analyzed John 21:15-19 by perspective of some experts. This paper uses text analysis methode of some experts' perspectives, they are: Brown, Bartholomew, and Tilborg. The result of analysis shows that love is not about fulfilling ego but about dedication for others. Love is willingness to nurture life. Finally, love always comes with sucrifice. Love is a self dedication. In a dedication, there always comes with joy and sorrow even sometimes also suffering.
\end{abstract}

Keywords: love, God, dedication, sucrifice, suffering.

\section{PENDAHULUAN}

Dalam Kamus Besar Bahasa Indonesia, kasih adalah perasaan sayang (cinta) kepada seseorang. Sedangkan mengasihi bermakna menaruh kasih kepada; mencintai; menyayangi. Dalam ajaran Kristiani, salah satu definisi kasih (cinta) adalah perintah, sebagaimana disebutkan dalam Alkitab, "Dan inilah kasih itu, yaitu bahwa kita harus hidup menurut perintah-Nya" (2 Yohanes 1: 6a). Selanjutnya, kasih atau cinta harus dibuktikan melalui tindakan atau perbuatan, "Anak-anakku, marilah kita mengasihi bukan dengan perkataan atau dengan lidah, tetapi dengan perbuatan dan dalam kebenaran” (1 Yohanes 3: 18). Kasih juga adalah sebuah pilihan, seperti dikatakan dalam 1 Korintus 14: 1, "Kejarlah kasih itu dan usahakanlah dirimu meperoleh karunia-karunia Roh, terutama karunia untuk bernubuat”. Dalam hal ini, Tuhan memerintahkan kita supaya saling mengasihi, tidak hanya melalui perkataan, melainkan juga melalui perbuatan atau 
tindakan, serta kita juga diberi pilihan untuk mengasihi tanpa harus diperintah. Seperti halnya Tuhan yang memilih untuk mengasihi kita.

Dalam Injil Yohanes disebutkan, "God is love ... If we love one another, God lives in us, and his love is perfected in us" (1 Yoh 4: 8-12). Selanjutnya, Yesus juga mengatakan, "Do not receive into the house or welcome anyone who comes to you and does not bring this teaching; for to welcome is to participate in the evil deeds of such a person" (2 Yoh: 10-11). Yesus mengatakan bahwa Yesus sendiri adalah kasih. Siapapun yang mengasihi sesamanya, maka Yesus akan tinggal dan berdiam dalam diri seseorang tersebut, namun akan sebaliknya jika siapapun mereka tidak taat pada perintah dan ajaranNya. Demikian juga dikatakan, "God so loved the world that he gave his only Son, so that everyone who believes in him may not perish but may have eternal life ... Whoever disobeys the Son will not see life; but must endure God's wrath” (Yoh 3: 16, 36). Dalam hal ini disebutkan tentang kasih Allah yang begitu besar kepada manusia. Allah mengajarkan bahwa dalam mengasihi atau mencintai selalu ada sebuah pengorbanan sebagai wujud pemberian diri kepada yang dikasihi. Sekaligus, siapapun yang percaya, maka mereka akan memperoleh kehidupan kekal.

Kasih juga merupakan ungkapan yang fundamental dari seorang murid terhadap gurunya yaitu Yesus. Seperti yang tersebut dalam Injil Yohanes, "Sementara itu sebelum hari raya Paskah mulai, Yesus telah tahu, bahwa saatnya sudah tiba untuk beralih dari dunia ini kepada Bapa. Sama seperti Ia senantiasa mengasihi murid-muridNya demikianlah sekarang Ia mengsihi mereka sampai kepada kesudahannya” (Yoh 13:1). Yesus telah mengajarkan dan menanamkan kasih itu di dalam diri para muridnya. Selanjutnya, Yesus mengatakan "Inilah perintahKu, yaitu supaya kamu saling mengasihi, seperti Aku telah mengasihi kamu" (Yoh 15:12). Kasih adalah tanda krusial dalam ajaran dan perbuatan Yesus. Bagi Yesus, ekspressi tertinggi dari kasih seseorang adalah "memberikan nyawanya untuk sahabat-sahabatnya” (Yoh 15:13). Ekspressi tertinggi ini merupakan sebuah tuntutan dalam mengikuti Yesus. Hidup seperti Yesus berarti hidup bukan untuk diri sendiri melainkan bagi orang lain, memelihara, menyelamatkan sampai mati.

Dari beberapa pengertian kasih yang tersebut dalam Injil Yohanes, tulisan ini hendak menguraikan tuntutan kasih sebagaimana diwajibkan dalam Yoh 21: 15-19 mengenai pertanyaan tentang kasih, yang disampaikan oleh Yesus kepada Petrus sampai tiga kali berturut-turut, "Simon, anak Yohanes, apakah engkau mengasihi Aku lebih dari pada mereka ini?”. Pertanyaan tersebut membuat Petrus merasa tidak nyaman. Apa sebenarnya definisi kasih dan mengasihi? Pertanyaan inilah yang menjadi sumber motivasi utama penulis dalam memilih judul untuk tulisan ini. 
Tulisan ini hendak menguraikan apa itu kasih dan tuntutannya menurut teks dalam Injil Yoh 21: 15-19 untuk memperoleh pemahaman yang lebih baik, sekaligus menjadi pendapat penulis tentang apa artinya mengasihi Yesus dan orang lain, yaitu sesama. Sering terjadi, orang yakin bahwa mereka mencintai orang lain, padahal mereka hanya memanfaatkan orang lain secara tersembunyi demi kepentingan dirinya. Orang kadang-kadang gagal memenuhi tuntutan cinta dengan baik.

Teks ini, mengungkapkan pertanyaan tadi: apa sebenarnya mengasihi itu? Ulasan tentang pertanyaan ini akan dilaksanakan secara bertahap: pertama, memberikan struktur teks sebagaimana kita lihat dalam Injil Yohanes, kemudian dilanjutkan dengan analisa dan komentar beberapa ahli. Analisa biblis para ahli ini menyediakan informasi yang bermanfaat untuk menemukan jawaban dari pertanyaan di atas: apa artinya mengasihi? Penemuan itu akan saya tuliskan pada bagian akhir dari artikel ini sekaligus sebagai sebuah kesimpulan.

\section{PEMBAHASAN}

\subsection{STRUKTUR TEKS}

Ada beberapa struktur teks yang digunakan penulis sebagai rujukan dalam mendefinisikan kasih dan mengasihi dalam Injil Yohanes, antara lain: (15a) Pengantar, (15b) Pertanyaan Yesus dan jawaban Petrus, diikuti dengan tuntutan, (16-17) Ulangan dari pertanyaan dan jawaban yang sama, diikuti dengan tuntutan yang sama, diulangi sampai tiga kali, (18) Penjelasan tuntutan dengan menunjuk (referensi) keadaan Petrus ketika muda dan ketika tua. Keadaan Petrus yang demikian adalah keadaan manusia pada umumnya, serta (19) Tafsiran referensi, diikuti dengan sebuah kesimpulan.

\subsection{ANALISIS TEKS}

15a "Sesudah sarapan”. Menurut para ahli waktu sesudah sarapan bukan indikasi waktu yang sesungguhnya. Momen sesudah sarapan bermakna fisial. Tujuannya hanya untuk menciptakan hubungan antara bab 21: 15-17 dan bab 21:12-13, sekaligus sebagai sebuah catatan pengantar ke peristiwa berikutnya.

15b-17 “Apakah engkau mengasihi Aku ... Engkau tahu, bahwa aku mengasihi Engkau... Gembalakanlah domba-dombaKu”. Dalam bahasa Yunani, ada dua kata kerja untuk kata "mengasihi” yaitu agapan artinya kasih dan philein artinya persahabatan. Menurut komentator bangsa Yunani yaitu John Chrysostom dan Cyril dari Alexandria, serta para ahli dari zaman reformasi seperti Erasmus, mereka belum melihat perbedaan arti dari variasi dua kosakata tersebut. Sejumlah ahli zaman modern juga mengatakan bahwa variasi tersebut kurang bermanfaat untuk memahamai teks (Brown 1970: 1104). R. Brown misalnya, menganalisis 
kata kerja “mengasihi” melalui pertanyaan dan jawaban Bab 21: 15-17, variasinya sebagai berikut:

$$
\begin{aligned}
& \text { 15: Agapas me ... philo se } \\
& \text { 16: Agapas me ... philo se } \\
& \text { 17: Agapas me... philo se (Brown 1970: 1104) }
\end{aligned}
$$

Dari analisa tersebut di atas, mucul sebuah pertanyaan: apakah Yesus menanyakan bentuk kasih yang lebih agung (agapan) dari Petrus, tetapi kemudian Petrus menjawab pertanyaan itu dalam bentuk kasih yang lebih rendah yaitu persahabatan (philein)? atau apakah Yesus meminta kasih yang khusus (agapan) tetapi kemudian Petrus mengekspresikan afeksi personal (philein)?, atau sebaliknya.

Adapun persoalan yang mungkin, tidak ada perbedaan arti yang signifikan antara agapan dan philein dalam ayat 15-17. Jawaban "Ya" dari Petrus terhadap Yesus sama dengan ekspresi kata kerja agapan. Walaupun Petrus mengekspresikannya dalam kata philein, hal itu tidak memperlihatkan kesadaran bahwa Petrus menjawab permintaan untuk bentuk kasih yang lebih tinggi atau lebih relasional dari kasih agapan.

Ide yang sama ditemukan dalam pendapat Gilbert L. Bartholomew yang mengambil contoh dari Bab 14: 23 dan Bab 16:27, ketika Yesus menyampaikan kepada para muridnya, bila seseorang mengasihinya, Bapanya juga akan mengasihi orang itu. Dalam bagian sebelumnya, kata kerja yang dipakai ialah agapao dan kemudian phileo. Dalam Bab 15: 13, Yesus mengajarkan bahwa hal yang paling besar ialah kasih agape, dan rela memperlihatkan kasih itu dengan "memberikan nyawanya untuk sahabat-sahabatnya” philon. Dalam Bab 21: 1519, hal yang dijanjikan Petrus ialah memberikan nyawanya untuk Yesus (Bartholomew 1987: 39 - 40).

Menurut R. Brown, banyak dari para ahli yang berpendapat bahwa tiga kali pengulangan pertanyaan yang sama "apakah engkau mengasihi Aku?" dari Yesus dan tiga kali pengulangan jawaban yang sama dari Petrus, "Engkau tahu bahwa aku mengasihi Engkau” adalah simbol dari tiga kali penyangkalan Petrus. Petrus membaharui kemuridannya setelah ia gagal sebagaimana tampak dalam jawabannya (Brown 1970: 1111). Ide yang sama terdapat dalam karya Sjef van Tilborg, Yesus bertanya tiga kali “apakah kamu mengasihi Aku?” dan Petrus menjawab "Engkau tahu bahwa aku mengasihi Engkau.” Perikop ini merujuk pada bab 13:36-38, dimana Petrus mengatakan bahwa dia akan menyerahkan hidupnya untuk Yesus, sementara Yesus sudah menduga bahwa Petrus akan mengingkarinya sampai tiga kali. Setelah Petrus memberikan jawabannya, Yesus mengatakan, “gembalakanlah domba-dombaku”. Perkataan Yesus tersebut adalah 
penugasan yang mengandung tuntutan. Tuntutan itu adalah kesediaan untuk menyerahkan hidupnya demi domba (Tilborg 1993: 155).

Lebih jauh, R. Brown mengatakan, menggembalakan domba-domba adalah tuntutan dari kasih. Yesus menugaskan Petrus untuk menggembalakan domba-domba sebagai wujud kasih dari Petrus. Bagi Yesus, kasih yang dituntut dari Petrus adalah dalam wujud menggembalakan domba. Menurut para ahli, Yesus, pertama-tama, menanyakan kasih Petrus. Hal itu terjadi karena tugas Petrus sebagai gembala harus dilaksanakan dalam kasih kepada domba. Kalau Petrus sungguh memberikan hidupnya kepada Yesus, Yesus dapat mempercayakan kawanan dombanya kepadanya dengan syarat Petrus taat pada kehendak Yesus atau meniru cara Yesus melaksanakan tugas penggembalaannya (Brown 1970: 1115).

Menggembalakan domba-domba kurang mendapat tekanan bila dibandingkan dengan misi yang diembankan kepada Petrus yakni sebagai gembala. Dia tidak menjadi superior terhadap domba-dombanya. Petrus diminta untuk menggembalakan, artinya akrab dengan mereka, berdedikasi juga bila nyawanya terancam dalam pelaksaan misi tersebut. Jadi, dia melaksanakan perintah tersebut sungguh karena dedikasi dan kasihnya kepada Yesus gurunya dan domba-domba.

Yesus mengenal Petrus dengan baik. Petrus sombong, dia mengatakan bahwa dia mengasihi Yesus lebih dari siapapun dan dia bersedia memberikan hidupnya untuk Yesus (13:35), tetapi akhirnya Petrus mengkhianati Yesus. Akan tetapi sesudah itu, Yesus membaharui Petrus. Perintah untuk menggembalakan domba-domba yang diikuti dengan pembaharuan diri Petrus memperlihatkan bahwa Petrus dijadikan gembala bukan karena Petrus layak, melainkan karena kesediannya. Oleh karena dedikasinya kepada kawanan domba, gurunya menyerahkan tugas itu padanya. Pilihan Petrus memperlihatkan karya Allah dalam kerapuhan ciptaan, sesuatu yang merupakan bagian dari dunia ini.

17, Petrus sedih karena Yesus berkata untuk ketiga kalinya, "apakah engkau mengasihi Aku?”. Hal ini membawa kita pada sebuah tafsiran, yang mengandaikan sebuah kesedihan dalam diri Yesus juga, seperti dia katakan kepada muridnya: "apakah kamu percaya kepadaku sekarang; lihatlah waktunya akan tiba... Kamu meninggalkan saya seorang diri” (16:31-32). Ini adalah sebuah nubuat, ungkapan kenabian yang menunjuk keadaan para muridnya, khususnya Petrus. Yesus mengharapkan kasih Petrus. Petrus memahami dengan baik apa yang diminta oleh Yesus dari padanya.

Pemahaman ini sungguh penting karena bimbingan atau permintaan itu berdasar pada relasi guru dan murid. Selanjutnya, Petrus memahami dengan lebih baik tentang tuntutan dari kasihnya kepada Yesus daripada sebelumnya. Itulah sebabnya Petrus bersedia memberikan dirinya untuk kawanan domba. Menurut R. 
Brown, kematian Petrus adalah bukti ketulusan Petrus atas tiga kali pengulangan janjinya kepada Yesus, "tidak ada orang yang mempunyai kasih yang lebih besar dari orang yang memberikan hidupnya untuk yang dicintainya” (Brown 1970: 1117).

S. Van Tilborg mengatakan, ayat 18-19 adalah bagian penutup dari perikop ini. Pencerita berbicara dari perspektif post factum, dia tahu tentang akhir hidup Petrus. Kematian Petrus akan menjadi seperti kematian Yesus, sebagaimana telah dikatakan Yesus. Dengan itu, Petrus memenuhi undangan Yesus “follow me” (21:19) dalam (Tilborg 1993: 155). Petrus dipanggil Yesus untuk menjadi gembala yang baik (Good Sepherd). Perintah "Ikutlah Aku” identik dengan misi penggembalaan (sheperding mission). Misi penggembalaan yang diemban oleh Petrus adalah melanjutkan karya cinta (the work of love) sebagaimana ditampilkan oleh Bapa dan Putera sebagai Gembala. Seorang gembala harus pertama-tama memiliki cinta kepada Yesus, bukan pada dirinya sendiri, supaya bisa merawat, menjaga memberi makan domba-domba sebagaimana diteladankan oleh Sang Gembala Agung yang mencintai Petrus tanpa syarat.

\section{KESIMPULAN}

Kasih merupakan sebuah ungkapan fundamental dari seseorang kepada orang yang dikasihi. Kasih merupakan pemberian diri kepada orang yang dicintai sehingga ada relasi mendalam. Dalam relasi seperti ini, ada kerinduan untuk mencintai yang lain, menerima dan mengampuni. Dalam setiap relasi kadangkadang terjadi kesalahpahaman karena keegoisan yang menghalangi kita untuk melihat dan menjawab kebutuhan orang lain. Dalam situasi seperti ini, pengampunan amat sangat dibutuhkan demi kasih seperti yang dilakukan Yesus kepada Petrus.

R. Brown dan S. van Tilborg mempunyai pendapat yang sama yaitu Petrus membaharui diri setelah mengingkari Yesus. Yesus meminta Petrus menggembalakan domba-dombanya karena Petrus mengasihinya. Selanjutnya, Yesus mempercayakan dombanya kepada Petrus. Sebagai seorang gembala, apalagi gembala yang baik, Petrus seharusnya tidak berlaku sebagai tuan terhadap domba, melainkan sebagai orang yang memberikan dirinya untuk domba. Dombadomba itu bukan sebagai miliknya, melainkan sebagai milik gurunya. Inilah bentuk kasih antara Yesus dan Petrus.

Akhirnya, kasih selalu disertai pengorbanan, sebuah dedikasi yang menuntut pemberian diri untuk orang yang dikasihi. Dedikasi ini selalu memiliki dua wajah, didalamnya selalu terjadi saat-saat gembira dan sedih, bahkan kadangkadang juga penderitaan. Inilah pesan kasih yang disampaikan Injil Yohanes. 


\section{DAFTAR PUSTAKA}

Gilbert L, Bartholomew, 1987, “Feed My Lambs: John 21:15-19 as Oral Gospel,” in Semeia, pp.39.

Liu, Qingping, 2007, “On A Paradox of Christian Love” dalam Journal of Religious Ethics pp.684, Inc.

, 2007, “On A Paradox of Christian Love” dalam Journal of Religious Ethics pp.691, Inc.

Kim, S. S, 2017, “The Delayed Call for Peter in John 21:19: To Follow in and by His love” Neotestamentica, 51 (1), pp. 41-63.

R. Brown., 1970, The Gospel according to John, New York.

Tilborg, S Van., 1993, Imaginative Love in John, Leiden.

Schneiders, Sandra M., 2003, Written that you may believe, New York.

Peeters., 2018, “Studies In Spirituality”, Vol 28, Titus Brandsma Institut, Louvain. 